\title{
Evidence-based phytotherapy in allergic rhinitis
}

\author{
Vladimir Kozlov ${ }^{1 *} \mathbb{D}$, Galina Lavrenova², Elena Savlevich ${ }^{1}$ and Kira Bazarkina ${ }^{1}$
}

\begin{abstract}
Allergic rhinitis is one of the most important medical conditions; with around $10-25 \%$ of the global population suffering from allergic rhinitis. Allergic rhinitis also increases the risk of bronchial asthma, chronic sinusitis, and otitis media. While allergen-specific immunotherapy, antihistamine drugs, cromones, and topical and systemic corticosteroids are commonly used for the treatment of allergic rhinitis, phytotherapy for allergic rhinitis as alternative treatment is not commonly employed world-wide. Furthermore, like conventional therapies, specific plants may demonstrate adverse effects as they may possibly act as sources of allergens, which can cause immediate or delayed-type allergic reactions resulting in unexpected clinical manifestations.

Despite the prevalence of a generally critical and sceptical attitude towards the use of phototherapy for treatment of allergic rhinitis, the search for herbal drugs for the treatment of this disease is underway. In this regard, some studies confirm a lack of efficacy for some herbal medicine, while other trials provide evidence for relatively high efficacy of phytodrugs for the treatment of allergic rhinitis. Despite the shortcomings of many of these trials, the findings of efficacy and safety from these trials for the different preparations appear to be promising, and have encouraged an increasing number of studies to search for new medical herbs or their combinations for allergic rhinitis therapy. This article reviews the available evidence-based information on the experience of phototherapy for allergic rhinitis employed in oriental and European medicine.
\end{abstract}

Keywords: Phytotherapy, Allergic rhinitis, Treatment, Herbal drugs

\section{Review}

In modern otolaryngology allergic rhinitis is one of the most important conditions, which has demanded foremost attention of clinicians for years [1]. According to the ARIA guidelines, allergic rhinitis can be defined globally as a disease of the nasal mucosa, that is characterized by IgE-mediated inflammation of nasal cavity and daily symptoms; including nasal obstruction, nasal discharge (rhinorrhea), sneezing, and nasal itch; manifesting for at least $1 \mathrm{~h}$ or more on the daily basis [2].
Mechanistic studies have demonstrated that a sensitizing/triggering allergen interacts with specific IgE on the surface of mast cells located between epithelial cells and subepithelially in the nasal mucosa. The specific IgE is bound to membranes of mast cells and basophils via high affinity Fc-receptor type I, and when two and more IgE molecules are cross bound by the allergen, the receptors come together activating mast cell degranulation and release of pro-inflammatory mediators. Consequently, an acute phase with initial neurogenic and vascular damages develops within several seconds to several minutes post contact with the allergen.

\footnotetext{
* Correspondence: vladimir_kozlov@mail.ru

${ }^{1}$ Central state medical academy of Department of Presidential affairs Russian

Federation, 15, Marshala Timoshenko Street, 121356 Moscow, Russia

Full list of author information is available at the end of the article
} 
Cell infiltration unfolds throughout $2-8 \mathrm{~h}$ reaching the peak within 1-3 days, and lead to the symptoms of allergic rhinitis. It is now well documented that several key mediators, including histamine and tryptase (early phase), cytokines IL-4, IL-6, IL-13, chemokines, and PGD2 and LTC4 (late phase), play vital roles in the cascade of allergic reactions, which lead to the clinical symptoms of disease. Antigen-presenting cells process allergens and present them to Th2 lymphocytes, which produce IL-4, IL-5, IL-13. This causes the differentiation of B-lymphocytes into the plasma cells producing antibodies. As a result of intercellular interaction, chemotactic mediators (IL-5, IL-8, IL-13, LTB4, RANTES) play an important role in attracting an inflammatory cell in the mucous membrane of the nasal cavity [3-6].

Presently, allergen-specific immunotherapy [7-9], antihistamine drugs [10,11], cromones [12], topical and systemic corticosteroids [13-18] are used for the treatment of allergic rhinitis. In contrast, the use of alternate forms of therapy for treatment of allergic rhinitis is very limited and evidence for clinical efficacy in well controlled trials is contradictory; however, evidence suggests that some herbal medicines may be efficacious for the treatment of allergic disease. Thus, this study aims to review the available information on phytotherapy of allergic rhinitis.

\section{Methods}

Randomised controlled trials were identified by searching PUBMED, MEDLINE, Embase, hand searching article reference lists and through contact with local experts in the field. The terms used for research were: phytotherapy, allergic rhinitis, treatment, herbal drugs, efficacy of herbal compounds.

\section{Efficacy of herbal compounds}

It has been estimated that about $10-25 \%$ of the global population suffers from allergic rhinitis. In the USA the number of patients with allergy exceeds 40 million, with 25-30 million patients having allergic rhinitis [19]. Similarly, in England the prevalence of allergic rhinitis has been estimated to be $16 \%$, in Denmark 19\%, in Germany between 13 and 17\%, and in the Russian Federation between 12 and $24 \%$, depending on the different regions [3, 20-22]. Furthermore, allergic rhinitis increases the risk of bronchial asthma, chronic sinusitis, otitis media, as well as cognitive, emotional, and performance-related problems in childrenand adults [18, 23-25].
Therefore, in terms of prevalence and medical and social relevance, the impact on health and quality of life effects of allergic rhinitis is one of the most urgent issues facing both the patient and society alike $[2,26]$.

Evidence-based pharmacotherapies commonly employed in the management of allergic rhinitis are well documented and used world-wide [2]. Although, several herbs/medicinal plants have been used as complementary and alternative therapies for asthma, allergy, and immunological conditions, the use of many of these is often not based on unequivocal clinical evidence and many have been shown to be associated with significant adverse effects [27]. For example, while the Echinacea (Echinacea augustifolia, Echinacea pallida, and Echinacea purpurea), is one of the most common herbs used for the treatment of upper respiratory inflammation and allergy, this is also associated with the risk of hepatotoxicity, and aggravation of allergy, asthma and anaphylactic reactions. Similarly, other herbal preparations, including garlic, angelica, German chamomile flower, ephedra, gingko, grape seed extract, licorice root, St. John's worth, kava kava rhizome, peppermint, stinging nettle, and ginseng, are associated with significant adverse effects [27]. Moreover, garlic, ginger, ginkgo, ginseng, and St. John's wort have been reported to interact with conventional drugs and might possibly lead to moderate or serious adverse reactions, or even life-threatening events [28].

Nevertheless, there are several reports of well-controlled studies detailing phytotherapy of allergic rhinitis. As Chinese, Japanese (Kampo) and Indian (Ayurvedic) medicine advocates the wide use of herbs and mixtures of herbs for the treatment of various diseases, including asthma and allergic rhinitis, the efficacies of some of these have been investigated in well-controlled trials in subjects with allergic rhinitis. The findings of many of these trials need to be confirmed in larger, more rigorously designed clinical trials.

Using a similar study design, Zhao and colleagues [29] recently investigated the effects of Shi-Bi-Lin; a Chinese herbal formula based on the ancient traditional Chinese herbal formula Cang Er Zi San; in a cohort involving 125 patients with perennial allergic rhinitis. The authors demonstrated this preparation also to be safe and significantly effective in relieving some symptoms of perennial allergic rhinitis, improving the nose condition, and enhancing some domains of quality of life compared to placebo.

Although, the mechanisms underlying the efficacies of the Chinese herbal preparations are not entirely clear, one study investigating the putative mechanisms underlying the effects of Biminne in a murine model of airway allergy has suggested that 
Biminne treatment significantly down-regulated the Th2 cells and cytokines IL-4 and IL-5, and up-regulated the Th1 cells and IFN- $\gamma$, compared to control untreated mice; suggesting that Biminne may reduce allergic airway disease by decreasing or reversing the Th2/Th1 ratio towards the control level [30]. Another study investigating the mechanisms underlying the effects of Shi-Bi-Lin has demonstrated this preparation to be capable of reducing activity of a human mast cell line (HMC-1) and inhibiting the synthesis of IL-4 and TNF- $\alpha$ and to an insignificant extent IL-6 in vitro [31]. Similarly, a very recent study investigating the putative mechanism underlying the efficacy of the Japanese traditional medicine Senn-kinn-naidaku-sann (SKNS) in a murine model of allergic rhinitis indicated that this herbal preparation inhibited Th2 responses by enhancement of IL-12 release from macrophages via up-regulation of Toll-like receptor 4 (TLR4) expression [32]. The authors suggested that traditional Japanese medicine improves immunological activity by activating macrophages, reinforcing cell activity of NK-cells and exerting stimulating effect on hemopoietic stem cells.

The effect of non-Chinese herbal medicines for treatment of allergic rhinitis has also been investigated, with limited success. In one randomized double-blind placebo-controlled clinical trial, Bernstein et al. [33] investigated the efficacy and safety of grape seed extract in subjects with seasonal allergic rhinitis given $100 \mathrm{mg}$ twice daily for 8 weeks prior to the ragweed season. The subjects evaluated the symptoms of allergic rhinitis daily, quality of life at baseline and after 4 and 8 weeks' treatment, and necessity for the rescue antihistamine drug chlorpheniramine over the course of treatment. No significant differences were noted between active therapy and placebo within 8 weeks of therapy for any of these outcome measures, suggesting that grape seed therapy was unlikely to be efficacious for treatment of allergic rhinitis.

One of the first studies of the anti-inflammatory activity of an extracts of butterbur (Petasites hybri$d u s$ ) in allergic rhinitis were carried out by Thomet O. A. et al. [34]. In vitro studies Thomet O. A. et al. were suggested that an extract of Petasites hybridus (Ze339) blocks LT synthesis in monocytes and granulocytes. Authors are considered that Petasins to be the pharmacologically active fraction within Ze339. Patients suffering from allergic rhinitis received three times a day two tablets of Ze339 standardized to $8 \mathrm{mg}$ petasins within a time period of 1 week. After 5 days of treatment, Ze339 significantly improved primary end points, which were day- and nighttime nasal symptoms. Nasal resistance, which was measured by rhinomanometry, gradually decreased as a consequence of Ze339 treatment reaching normal levels after 5 days (rhinomanometry: from $403.5+/-62.0$ to $844.8+/-$ $38.8 \mathrm{ml}$ ). Levels of inflammatory mediators in nasal fluids and serum were measured 90 min after drug administration every day in the morning. After 5 days of treatment, a significant reduction of histamine (from $153.7+/-32.1$ to $53.0+/-8.4 \mathrm{pg} / \mathrm{ml}$ ) and LT levels (LTB4: from $313.1+/-46.5$ to $180.6+/-$ $32.2 \mathrm{pg} / \mathrm{ml}$; cysteinyl-LT: from $137.0+/-42.2$ to 70.1 +/-16.5 pg/ml) could be observed. Moreover, quality-of-life scores significantly improved. The drug had no effect on the distribution of lymphocyte subpopulations in the blood as well as on the capacity of blood leukocytes to generate cytokines and lipid mediators. These results suggest that Ze339 is effective in treating allergic rhinitis patients by decreasing levels of nasal inflammatory mediators [35].

Then the efficacy of butterbur (Petasites hybridus) in the treatment of seasonal allergic rhinitis has been investigated in several randomized, double-blind, placebo- or non-sedating antihistamine-controlled trials [36]. While three of these placebo-controlled trials showed $P$. hybridus to be effective for relief of symptoms or improved peak nasal inspiratory flow, another two comparing $P$. hybridus with cetirizine and one comparing it with placebo found no significant differences between the treatments for any outcomes. However, an open postmarketing surveillance study involving 580 patients treated with an average of 2 tablets of butterbur extract Ze 339 daily for 2 weeks and evaluated for symptoms; including rhinorrhea, sneezing, nasal congestion, itchy eyes and nose, red eyes, and skin irritation using a visual analogue scale; has demonstrated that symptoms of seasonal allergic rhinitis improved in $90 \%$ of patients [37]. Furthermore, all symptoms were improved significantly and were clinically relevant, at the end of therapy, compared to baseline; with $80 \%$ of patients positively rating efficacy, $92 \%$ positively rating tolerability, and $80 \%$ positively rating improvement in quality of life. Additionally, treatment by a combination of Ze 339 and anti-allergic medication did not result in a better effect than that attained with $\mathrm{Ze}$ 339 monotherapy. More recently, Skoner and colleagues [38] have compared the efficacy of $100 \mathrm{mg}$ butterbur with $10 \mathrm{mg}$ cetirizine treatment daily for 4 weeks in patients with perennial allergic rhinitis and demonstrated that both drugs were equally effective, as indicated by improvements in symptoms and quality of life scores. 
Similarly, well-controlled studies of lesser investigated herbal preparations have demonstrated statistically significant effects for Aller-7/NR-A2 (a polyherbal formulation prepared from extracts from seven medicinal plants) [39] Tinospora cordifolia [40] and Perilla frutescens [41] in the improvements of several outcome measures, including nasal symptoms (rhinorrhoea, sneezing, obstruction and itching), peak nasal flow rate and mucociliary clearance time, as well as quality of life in allergic rhinitis patients. Homeopathy includes the drugs that potentiate and alleviate nasal inflammatory symptoms, as well as modify the rheological properties of nasal discharge. One such homeopathic drug is Coryzalia (Laboratoires Boiron, France), which is used for the treatment of rhinitis of various origins, i.e. viral, infectious and allergic. This drug contains extracts of Alium cepa (onion), Atropa belladonna (belladonna) Sabadilla ocinarum (sabadilla, Ranunculaceae), Kalium bichromicum (potassium bichromate), Gelsemium sempervirens (yellow jasmine), Pulsatilla vulgaris (pasqueflower); of which practical homeopathy recommends Alium cepa for the treatment of seasonal or perennial allergy, Pulsatilla for effective treatment of nasal obstruction and excessive mucous discharge, Gelsemium sempervirens for relief of headache, weakness and fatigue, and nasal discharge, and Kalium bichromicum for improvement of nasal breathing in nasal mucosa damage with viscous mucus. Atropa belladonna is recommended by clinical guidelines for use at the initial stages of inflammatory respiratory diseases with intoxication syndrome, without catarrhal signs.

One study has investigated the efficacy of Coryzalia in a cohort of 110 children, aged 5-16 years old, suffering from persisting perennial allergic rhinitis [21]. The subjects were divided into three groups; with five subjects in group 1 with mild allergic rhinitis receiving Coryzalia monotherapy; 65 patients in group 2 with mild to moderate allergic rhinitis receiving Coryzalia as part of the complex treatment including irrigation therapy, systemic antihistamine drugs of second generation, nasal sprays; and 40 patients in group 3 with mild to moderate disease receiving conventional complex therapy of allergic rhinitis only. Efficacy assessment was performed by subjective scoring on a 5-point visual analogue scale for each symptom (nasal obstruction, nasal discharge and its nature, sneezing and nasal itch) at baseline, in 5-7 days, on day 14 and 21 of therapy. At enrollment, all children showed impaired nasal breathing $(4.01 \pm 0.05 ; 4.18 \pm 0.05$ and $4.17 \pm 0.07)$, rhinorrhea $(4.03 \pm 0.07 ; 4.08 \pm 0.05$ and $4.02 \pm 0.23$ scores), sneezing $(2.67 \pm 0.23 ; 2.74 \pm 0.30$ and $2.69 \pm$
0.4 scores $)$ and nasal itch $(2.7 \pm 0.25 ; 2.31 \pm 0.27$ and $2.54 \pm 0.27$ scores) in the three groups, respectively $(p>0.05)$. Comparative analysis of changes in severity of clinical symptoms showed progressively significant improvements in all groups; with 1.5-fold reduction of severity noted in all symptoms on days $5-7,2-2.5$-fold reduction in severity of symptoms noted on day 14, and maximum reduction in severity of symptoms noted on day 21 of therapy. Furthermore, tolerability to Coryzalia was assessed as "good" and "very good" by most subjects. The authors noted that Coryzalia monotherapy of mild allergic rhinitis allowed complete elimination of the disease avoiding vasoconstrictor drops, whereas addition of Coryzalia into complex therapy of children with perennial allergic rhinitis ensured a fast and significant alleviation of the symptoms of the disease. The authors suggested that Coryzalia reduces duration of the course of vasoconstrictor drugs and systemic antihistamine drugs of the second generation and therefore the pharmacological load for treatment of allergic rhinitis [21].

In one recent study, Ikromov and colleagues [42] used a combination of ultrasound disintegration of inferior concha with subsequent postoperative prescription of herbal calendula and milfoil decoction, for the treatment of patients with allergic rhinitis. Following the herbal treatment, the nasal rhinocytograms of patients revealed significant reduction of eosinophil, neutrophil and epithelia cell counts, and there was clinicallyimproved nasal breathing in all cases. Similarly, a single-blind study in subjects with seasonal allergic rhinitis investigating the effects of combining acupuncture and Chinese herbs has demonstrated significant alleviation of symptoms and improved quality of life compared to the effect of imitated acupuncture and non-specific herbs [43].

The effect of Nigella sativa (Black onion seed) has also been investigated for the treatment of allergic rhinitis [44]. A cohort of 66 patients with allergic rhinitis were evaluated for the effects of endonasally applied $N$. sativa oil for 2 weeks, for the presence of symptoms of allergic rhinitis as well as IgE and eosinophil count in nasal wash. Following treatment, the presence of the nasal mucosal congestion, nasal itching, runny nose, sneezing attacks, turbinate hypertrophy, and mucosal palor was reduced during the first 2 weeks. Furthermore, a number of subjects had reduced IgE and eosinophil count in nasal discharge, suggesting that topical application of $N$. sativa oil attenuated the clinical symptoms of allergic rhinitis by stabilizing mast cell membranes [44]. 


\begin{tabular}{ll}
\hline Author & Compound \\
Nikakhlagh & Nigella sativa \\
S. et al. [44] & \\
& \\
& \\
Ikromov M. & Herbal calendula \\
K. et al. & and milfoil decoction. \\
[42] & \\
& \\
& \\
Zhang Q. & The traditional Chinese \\
et al. [43] & theory of acupuncture.
\end{tabular}

Takano $\mathrm{H}$. Perilla frutescens et al. [41]

Badar $\mathrm{V}$. A. et Tinospora cordifolia al. [40]

Saxena $V$.

Polyherbal formulation

S. et al. [39]

Skoner D.
P. et al. [38]

\section{Publication year}

and reference

2011.

http://www.ncbi.nlm.nih.gov/pubmed/20947211 66 patients

$N$. sativa could reduce the presence of the

nasal mucosal congestion, nasal itching, runny nose, sneezing attacks, turbinate hypertrophy, and mucosal pallor during the first 2 weeks (day 15).

2012.

http://entru.org/files/j_rus_LOR_2_2008.pdf

2014. http://www.ncbi.nlm.nih.gov/pubmed/25059460

2004 http://www.ncbi.nlm.nih.gov/pubmed/14988517 29 patients

Randomized Controlled Clinical Trial

80 patients

The nasal rhinocytograms of patients revealed significant reduction of eosinophil, neutrophil and epithelia cell counts, and there was clinicallyimproved nasal breathing in all cases.

Randomized Controlled Clinical Trial

140 patients

The results of this trial will demonstrate the efficacy of using acupuncture to treat allergic rhinitis.

Randomized Controlled Clinical Tria

Active treatment significantly decreased the numbers of neutrophils and eosinophils in nasal lavage fluid ( $P<0.05$ vs. placebo). As compared with placebo supplementation, supplementation with extract of Perilla frutescens enriched for rosmarinic acid resulted in a significant increase in responder rates for itchy nose, watery eyes, itchy eyes, and total symptoms $(P<0.05)$.

2005. Randomized Controlled Clinical Trial

http://www.ncbi.nlm.nih.gov/pubmed/15619563 75 patients

After Tinospora Cordifolia, eosinophil and neutrophil count decreased and goblet cells were absent in nasal smear. Tinospora Cordifolia significantly decreased all symptoms of allergic rhinitis

2004 Randomized Controlled Clinical Trial http://www.ncbi.nlm.nih.gov/pubmed/15689054 545 patients

The three major symptoms (sneezing, rhinorrhea and nasal congestion) of allergic rhinitis were significantly reduced. Significant improvement was also observed in absolute eosinophil count, mucociliary clearance time, peak expiratory flow rate and peak nasal flow rate.

2014

http://www.ncbi.nlm.nih.gov/pubmed/24992553 321 patients

After 4 weeks, cetirizine-treated subjects reported significant reductions in these RQLQ domain scores and in emotion domain scores compared with placebo-treated subjects $(p<0.05)$.

2006

Randomized Controlled Clinical Trial

http://www.ncbi.nlm.nih.gov/pubmed/16751170 580 patients Symptoms of seasonal allergic rhinitis improved in $90 \%$ of patients after 2 weeks.

2007. Randomized Controlled Clinical Trial http://www.ncbi.nlm.nih.gov/pubmed/18219828 (a systematic review) Sixteen eligible RCTs, testing 10 different herbal products against placebo or active comparator, were included. While three of these placebo-controlled trials showed $P$. hybridus to be effective for relief of symptoms or improved peak nasal inspiratory flow.

2002 received three times a day two tablets of 


\begin{tabular}{|c|c|c|c|}
\hline & & & $\begin{array}{l}\text { Ze339 standardized to } 8 \mathrm{mg} \text { petasins within a } \\
\text { time period of } 1 \text { week. After } 5 \text { days of } \\
\text { treatment, Ze } 339 \text { significantly improved } \\
\text { primary end points, which were day- and } \\
\text { nighttime nasal symptoms. After } 5 \text { days of } \\
\text { treatment, a significant reduction of histamine } \\
\text { and LT levels. }\end{array}$ \\
\hline $\begin{array}{l}\text { Bernstein } \\
\text { D. I. et al. [33] }\end{array}$ & Grapeseed extract & $\begin{array}{l}2002 . \\
\text { http://www.ncbi.nlm.nih.gov/pubmed/11926620 }\end{array}$ & $\begin{array}{l}\text { Randomized Controlled Clinical Trial } \\
\text { Over } 8 \text { weeks of treatment, no significant } \\
\text { differences were observed between active } \\
\text { and placebo groups in rhinitis quality of life } \\
\text { assessments, symptom diary scores, or } \\
\text { requirements for rescue antihistamine. }\end{array}$ \\
\hline $\begin{array}{l}\text { Morikura I. } \\
\text { et al. [32] }\end{array}$ & Sen-kinn-naidaku-sann & $\begin{array}{l}2014 . \\
\text { http://www.ncbi.nlm.nih.gov/pubmed/25271531 }\end{array}$ & $\begin{array}{l}\text { Randomized Controlled Laboratory Study } \\
\text { Oral administration of Senn-kinn-naidaku-sann } \\
\text { inhibits Th2 responses by enhancement of } \\
\text { IL-12 release from macrophages via } \\
\text { up-regulation of TLR4 expression. }\end{array}$ \\
\hline $\begin{array}{l}\text { Zhao Y. } \\
\text { et al. [31] }\end{array}$ & $\begin{array}{l}\text { Chinese herbal formula } \\
\text { Shi-Bi-Lin }\end{array}$ & $\begin{array}{l}2005 . \\
\text { http://www.ncbi.nlm.nih.gov/pubmed/16095146 }\end{array}$ & $\begin{array}{l}\text { Randomized Controlled Laboratory Study } \\
\text { Shi-Bi-Lin could modulate the mast } \\
\text { cell-mediated hypersensitivity reaction in } \\
\text { allergy. Inhibition of mast cell-derived IL-4 } \\
\text { and TNF-alpha might explain the efficacy of } \\
\text { SBL in treating allergic disease. }\end{array}$ \\
\hline $\begin{array}{l}\text { Zhang S. Q. } \\
\text { et al. [30] }\end{array}$ & $\begin{array}{l}\text { Chinese herbal } \\
\text { Formula Biminne }\end{array}$ & $\begin{array}{l}2009 . \\
\text { http://www.ncbi.nlm.nih.gov/pubmed/19361365 }\end{array}$ & $\begin{array}{l}\text { Randomized Controlled Laboratory Study } \\
\text { Biminne significantly relieved the inflammatory } \\
\text { reaction in the lung tissue of airway allergic } \\
\text { mice. }\end{array}$ \\
\hline $\begin{array}{l}\text { Zhao Y } \\
\text { [29]. }\end{array}$ & $\begin{array}{l}\text { Chinese herbal formula } \\
\text { Shi-Bi-Lin }\end{array}$ & $\begin{array}{l}\text { 2009. } \\
\text { http://www.ncbi.nlm.nih.gov/pubmed/19118617 }\end{array}$ & $\begin{array}{l}\text { Randomized Controlled Clinical Trial } \\
126 \text { patients } \\
\text { The improvement was sustained for at least } \\
2 \text { weeks after treatment. }\end{array}$ \\
\hline $\begin{array}{l}\text { Chen X.W. } \\
\text { et al. [28] }\end{array}$ & $\begin{array}{l}\text { Clinical herbal interactions } \\
\text { with conventional drugs }\end{array}$ & $\begin{array}{l}2011 . \\
\text { http://www.eurekaselect.com/75318/article }\end{array}$ & $\begin{array}{l}\text { Case Series } \\
\text { Discuss the mechanisms and clinical } \\
\text { implications of such herb-drug interactions } \\
\text { by reviewing published human studies. }\end{array}$ \\
\hline $\begin{array}{l}\text { Bielory L. } \\
{[27]}\end{array}$ & $\begin{array}{l}\text { A review of the literature of asthma, } \\
\text { allergy complementary and } \\
\text { alternative medicine published } \\
\text { between } 1980 \text { and } 2003 .\end{array}$ & $\begin{array}{l}2004 . \\
\text { http://www.ncbi.nlm.nih.gov/pubmed/15330011 }\end{array}$ & $\begin{array}{l}\text { A review of the literature } \\
\text { Almost all of the complementary } \\
\text { and alternative medicine interventions have } \\
\text { displayed adverse effects, usually in the form } \\
\text { of a hypersensitivity reaction. }\end{array}$ \\
\hline $\begin{array}{l}\text { Schenkel E. } \\
\text { J. et al. [17] }\end{array}$ & Mometasone furoate & $\begin{array}{l}\text { 2000. } \\
\text { http://www.ncbi.nlm.nih.gov/pubmed/10654982 }\end{array}$ & $\begin{array}{l}\text { Randomized Controlled Clinical Trial } \\
98 \text { patients ( } 82 \text { patients completed the study). } \\
\text { Absence of growth retardation in children } \\
\text { with perennial allergic rhinitis after } 1 \text { year of } \\
\text { treatment with mometasone furoate } \\
\text { aqueous nasal spray. }\end{array}$ \\
\hline Platt M. [16] & $\begin{array}{l}\text { A comprehensive review of } \\
\text { pharmacotherapies for allergic rhinitis was } \\
\text { performed using a PubMed search. }\end{array}$ & $\begin{array}{l}2014 \\
\text { http://www.ncbi.nlm.nih.gov/pubmed/25182353 }\end{array}$ & $\begin{array}{l}\text { A review of the literature } \\
\text { Pharmacotherapies for allergic rhinitis offer } \\
\text { numerous options that are safe, effective, } \\
\text { and readily available to target specific nasal } \\
\text { symptoms. }\end{array}$ \\
\hline Zaoui A. [43] & Nigella sativa & $\begin{array}{l}2002 \\
\text { https://www.ncbi.nlm.nih.gov/pubmed/ } \\
11924767\end{array}$ & $\begin{array}{l}\text { The acute toxicity of Nigella sativa fixed oil } \\
\text { was investigated in mice. LD50 values, } \\
\text { obtained by single doses, orally and } \\
\text { intraperitoneally administered in mice, } \\
\text { were } 28.8 \mathrm{ml} / \mathrm{kg} \text { body wt. p.o. [26.2-31.6] } \\
\text { and } 2.06 \mathrm{ml} / \mathrm{kg} \text { body wt. i.p. [1.86-2.26], } \\
\text { respectively. Chronic toxicity was studied in } \\
\text { rats treated daily with an oral dose of } 2 \\
\mathrm{ml} / \mathrm{kg} \text { body wt. for } 12 \text { weeks. }\end{array}$ \\
\hline
\end{tabular}




\section{Adverse events}

Minor side effects were reported in five cases concerning Nigella sativa, Herbal calendula, Tinospora cordifolia, Butterbur herbal, Grapeseed extract. Only the application of large doses of these herbs have been associated with minimal side effects: contact dermatitis, belching, headache, itchy eyes, gastrointestinal issues. For example, oil extracted from Nigella sativa seeds may cause kidney or liver damage when used in high doses. These possibly severe side effects of treatment were also observed in rats given $2 \mathrm{~g}$ per kilogram or more of Nigella sativa oil [45].

\section{Conclusions}

Despite the prevalence of a generally sceptic attitude adopted towards the use of phytotherapy for management of patients with allergic rhinitis, the use of herbal drugs has increasingly been investigated in the treatment of this disease, over the last decade. While some studies have demonstrated a lack of efficacy for some herbal therapies, other trials carried out using evidence-based medicine techniques have provided more convincing evidence for a relatively high efficacy of phytodrugs for the treatment of allergic rhinitis. In view of these promising findings, more research is currently underway to confirm the efficacy of these herbal preparations as well as to search for new medical herbs or their combinations as efficacious and safe alternatives to conventional pharmacotherapies for allergic rhinitis.

\section{Abbreviations \\ ARIA: Allergic Rhinitis and its Impact on Asthma; RQLQ: Rhinoconjunctivitis} and Rhinitis Quality of Life Questionnaire; SKNS: Senn-kinn-naidaku-sann

\section{Acknowledgements}

The authors also thank Dr. Jagdish Devalia for his help with editing this manuscript.

\section{Availability of data and materials}

Randomised controlled trials were identified by searching PUBMED, MEDLINE, Embase, hand searching article reference lists and through contact with local experts in the field. The terms used for research were: phytotherapy, allergic rhinitis, treatment, herbal drugs, efficacy of herbal compounds. Data from the Central Scientific Medical Library, Moscow.

\section{Authors' contributions}

VK: conceived of the presented idea, VK encouraged GL to investigate [a specific aspect] and supervised the findings of this work. GL: investigated specific aspect. ES: supervised the project, contributed to the final version of the manuscript. KB: wrote the manuscript with support from VK, GL and ES. All authors provided critical feedback and helped shape the research, analysis and manuscript. All authors read and approved the final manuscript.

\section{Authors' information}

Prof. Vladimir Kozlov is the Head of the Department of Otolaryngology at Central state medical academy of Department of Presidential affairs, Moscow, Russia.

Prof. Galina Lavrenova is the Head of the Department of Otolaryngology at The first Pavlov State medical university of Saint Peterburg, Russia. Dr. Elena Savlevich associated professor of the ENT department of Otolaryngology at Central state medical academy of Department of Presidential affairs, Moscow, Russia.
Kira Bazarkina is a postgraduate student at ENT department of Otolaryngology at Central state medical academy of Department of Presidential affairs, Moscow, Russia.

Ethics approval and consent to participate Not applicable.

\section{Consent for publication}

All authors read and approved the final manuscript.

\section{Competing interests}

The authors declare that they have no competing interests.

\section{Publisher's Note}

Springer Nature remains neutral with regard to jurisdictional claims in published maps and institutional affiliations.

\section{Author details}

${ }^{1}$ Central state medical academy of Department of Presidential affairs Russian Federation, 15, Marshala Timoshenko Street, 121356 Moscow, Russia. ${ }^{2} T$ The first Pavlov State Medical University of Saint Peterburg, 6-8, Lva Tolstogo Street, 197022 Saint Petersburg, Russia.

Received: 28 January 2018 Accepted: 21 June 2018

Published online: 06 August 2018

\section{References}

1. Rayka E. Allergy. Budapest: Publisher Hungarian Academy of Sciences; 1966.

2. ARIA (Allergic Rhinitis and its Impact on Asthma). In collaboration with the World Health Organization, GA2LEN and AllerGen. 2008. https://www. euforea.eu/assets/pdfs/aria/2008-ARIA-Report.pdf. Accessed 8 July 2018

3. Lopatin AS. Allergic rhinitis. Russ Med J. 2003;8:446.

4. Holmberg K, Bake B, Pipkorn U. Reflex activation in allergen-induced nasal mucosal vascular reactions. Acta Otolaryngol. 1989;108(|-2):130-5.

5. Kalrsson G, Pipkorn U. Natural allergen exposure does not influence the density of goblet cells in the nasal mucosa of patients with seasonal allergic rhinitis. ORL Otorhinolaryngol Relat Spec. 1989:51(3):171-7.

6. Siracusa MC, Kim BS, Spergel JM, Artis D. Basophils and allergic inflammation. J Allergy Clin Immunol. 2013; https://doi.org/10.1016/j.jaci. 2013.07.046

7. Aboshady OA, Elghanam KM. Sublingual immunotherapy in allergic rhinitis: efficacy, safety, adherence and guidelines. Clin Exp Otorhinolaryngol. 2014; 7(4):241-9.

8. Maloney J, Durham S, Skoner D, Dahl R, Bufe A, Bernstein D, et al. Safety of sublingual immunotherapy Timothy grass tablet in subjects with allergic rhinitis with or without conjunctivitis and history of asthma. Allergy. 2015; 70(3):302-9.

9. Wuthrich $B, C h$ B, Jorg W, Bircher A, Eng P, Schneider $Y$, et al. Double-blind, placebo-controlled study with sublingual immunotherapy in children with seasonal allergic rhinitis to grass pollen. J Invest Allergol Clin Immunol. 2003;13(3):145-8.

10. Geha RS, Meltzer EO. Desloratadine: a new, nonsedating, oral antihistamine. J Allergy Clin Immunol. 2001;107(4):751-62.

11. Kay GG. The effects of antihistamines on cognition and perfomanse. Allergy Clin Immunol. 2000;105:622-7.

12. Montoro J, Sastre J, Jauregui I, et al. Allergic rhinitis: continuous or demand antihistamine therapy? J Invest Allergol Clin Immunol. 2007;17(2):21-7.

13. Kryukov Al, Turovskiy AB, Bondareva GP, Semkina OV. Principles of the treatment of allergic rhinitis. Meditsinskiy sovet. 2013:7:42-7.

14. Lopatin AS. Rhinitis: pathogenetic mechanisms and principles of pharmacotherapy. Moscow: Litterra; 2013.

15. Van Cauwenberge P, Bachert C, Passalacqua G, Bousquet J. Consensus statement on the treatment of allergic rhinitis. Allergy. 2000;55(2):116-34.

16. Platt M. Pharmacotherapy for allergic rhinitis. Int Forum Allergy Rhinol. 2014; https://doi.org/10.1002/alr.21381.

17. Schenkel EJ, Skoner DP, Bronsky EA, et al. Absence of growth retardation in children with perennial allergic rhinitis after one year of treatment with mometasone furoate aqueous nasal spray. Pediatrics. 2000;105:22.

18. Waxman JE, Spector JG, Sale SA. Allergic Aspergillus sinusitis: concepts in diagnosis and treatment of a new clinical entity. Laryngoscope. 1987:97(3): $261-6$. 
19. Chaukina VA. Allergic rhinitis in the practice of primary care physician. Moscow: iDoctor; 2013. http://www.medvestnik.ru/library/article/12898. Accessed 21 Dec 2014

20. Ignatova IA, Smirnova SV, Manchuk VT. Allergic rhinosinusopathy (of true and pseudoallergic genesis). Dialog. 2007;17-8. http://www.dissercat.com/ content/allergicheskaya-rinosinusopatiya-u-zhitelei-vostochnoi-sibiri.

21. Karpova EP, Sokolova MV, Antonova NV. Peculiarities of therapy of allergic rhinitis in children. Newsl Otholaryngol. 2009;2:36-9.

22. Lavrenova GV. Treatment of subjects with allergic rhinosinusopathy. Newsl Otholaryngol. 1992;4:14-5.

23. Bender BG, Fisher TJ. Differential impacts of allergic rhinitis and allergy medications on childhood learning. Pediatr Asthma Allergy Immunol. 1998;12:1-13.

24. Richards W. Preventing behavior problems in asthma and allergies. Clin Pediatr. 1994;33:617-24.

25. Settipane RA. Complication of allergic rhinitis. Allergy Asthma Proc. 1999:20:209-13.

26. Lopatin AS. Allergic rhinitis: definition, classification, differential diagnosis. Russ Med J. 2002;3:100.

27. Bielory L. Complementary and alternative interventions in asthma, allergy, and immunology. Ann Allergy Asthma Immunol. 2004;93 (2):45-54.

28. Chen XW, Serag ES, Sneed KB, Liang J, Chew H, Pan SY, Zhou SF. Clinical herbal interactions with conventional drugs: from molecules to maladies. Curr Med Chem. 2011:18(31):4836-50.

29. Zhao Y, Woo KS, Ma KH, van Hansselt CA, Wong KC, Cheng KF, et al. Treatment of perennial allergic rhinitis using Shi-bi-Lin, a Chinese herbal formula. J Ethnopharmacol. 2009;122(1):100-5.

30. Zhang SQ, Shen ZY, Hu GR, Liu RH, Zhang XM. Effects of Chinese herbal formula Biminne in regulating endocrine-immune function in mice with airway allergy. J Chin Integr Med. 2009;7(4):349-53.

31. Zhao Y, van Hasselt CA, Woo JKS, Chen GG, Wong YO, Wang LH, Leung PC. Effects of the Chinese herbal formula Shi-bi-Lin on cytokine release from the human mast cell line. Ann Allergy Asthma Immunol. 2005;95(1):79-85.

32. Morikura I, Murata A, Aoi N, Shimizu Y, Fuchiwaki T, Prokopakis E, Kawauchi H. Japanese traditional medicine, Sen-kinn-naidaku-sann upregulates toll-like receptor 4 and reduces murine allergic rhinitis. Rhinology. 2014;52(3):252-9.

33. Bernstein DI, Bernstein CK, Deng CQ, Murphy KJ, Bernstein IL, Bernstein JA, Shukla R. Evaluation of the clinical efficacy and safety of grape seed extract in the treatment of fall seasonal allergic rhinitis: a pilot study. Ann Allergy Asthma Immunol. 2002;88(3):272-8.

34. Thomet OA, Wiesmann UN, Schapowal A, Bizer C, Simon HU. Role of petasin in the potential anti-inflammatory activity of a plant extract of petasites hybridus. Biochem Pharmacol. 2001;61(8):1041-7.

35. Thomet OA, Schapowal A, Heinisch IV, Wiesmann UN, Simon HU. Antiinflammatory activity of an extract of Petasites hybridus in allergic rhinitis. Int Immunopharmacol. 2002;2(7):997-100.

36. Guo R, Pittler MH, Ernst E. Herbal medicines for the treatment of allergic rhinitis: a systematic review. Ann Allergy Asthma Immunol. 2007;99(6):48395.

37. Käufeler R, Polasek W, Brattström A, Koetter U. Efficacy and safety of butterbur herbal extract Ze 339 in seasonal allergic rhinitis: postmarketing surveillance study. Adv Ther. 2006;23(2):373-84.

38. Skoner DP, LaForce CF, Nathan RA, Urdaneta ER, Zielinski MA, Sacavage SD, et al. Effect of cetirizine on symptom severity and quality of life in perennial allergic rhinitis. Allergy Asthma Proc. 2014;35(4):338-45.

39. Saxena VS, Venkateshwarlu K, Nadig P, Barbhaiya HC, Bhatia N, Borkar DM et al. Multicenter clinical trials on a novel polyherbal formulation in allergic rhinitis. Int J Clin Pharmacol Res. 2004:24(2-3):79-94.

40. Badar VA, Thawani VR, Wakode PT, Shrivastava MP, Gharpure KJ, Hingorani LL, Khiyani RM. Efficacy of Tinospora cordifolia in allergic rhinitis. J Ethnopharmacol. 2005;96(3):445-9.

41. Takano H, Osakabe N, Sanbongi C, Yanagisawa R, Inoue K, Yasuda A, et al. Extract of Perilla frutescens enriched for rosmarinic acid, a polyphenolic phytochemical, inhibits seasonal allergic rhinoconjunctivitis in humans. Exp Biol Med (Maywood). 2004;229(3):247-54.

42. Ikromov MK, Gulomov ZS, Nazirmadova MB. Phytotherapy in combination with ultrasound disintegration of inferior conch in the treatment of chronic hypertrophic rhinitis. Urgent issues of otholaryngology: materials of training conference, November 23-24, 2012; 2012. p. 30-1.
43. Zhang Q, Chen Q, Jiang L, Li X, Liu Y, Xie Y, et al. Effectiveness of strengthened stimulation during acupuncture for the treatment of allergic rhinitis: study protocol for a randomized controlled trial. Trials. 2014; https:// doi.org/10.1186/1745-6215-15-301.

44. Nikakhlagh S, Rahim F, Aryani FH, Syahpoush A, Brougerdnya MG, Saki N. Herbal treatment of allergic rhinitis the use of Nigella sativa. Am J Otolarynogol. 2011;32(5):402-7.

45. Zaoui A, Cherrah Y, Mahassini N, Alaoui K, Amarouch H, Hassar M. Acute and chronic toxicity of Nigella sativa fixed oil. Phytomedicine. 2002;9(1):69-74

\section{Submit your manuscript to a SpringerOpen ${ }^{\circ}$ journal and benefit from:}

- Convenient online submission

- Rigorous peer review

- Open access: articles freely available online

- High visibility within the field

- Retaining the copyright to your article

Submit your next manuscript at $>$ springeropen.com 